\title{
Emocionalna iskustva učitelja kao prediktori njihova mentalnoga zdravlja
}

\author{
Ivana Macuka, Irena Burić, Ana Slišković \\ Odjel za psihologiju Sveučilišta u Zadru, Hrvatska
}

\section{Sažetak}

Učiteljska je profesija emocionalno zahtjevna profesija te učitelji navode kako u svom poslu doživljavaju različite ugodne i neugodne emocije značajnoga intenziteta. Različite emocije koje učitelji doživljavaju u odnosu s profesionalnim aktivnostima mogu utjecati na njihov profesionalni, ali i osobni razvoj. Učestalo se doživljavanje negativnih emocija u svakodnevnom radu u odnosu s učenicima, roditeljima, kolegama i nadređenima, uz doživljaj emocionalne iscrpljenosti (kao važnog aspekta sagorijevanja na poslu) može nepovoljno odraziti na psihološku dobrobit učitelja te povećati zastupljenost i psihopatoloških simptoma.

U ovom je istraživanju ispitana uloga različitih emocija koje učitelji mogu doživjeti u odnosu s učenicima u razredu, roditeljima i obrazovnim sustavom, kao i doživljaj emocionalne iscrpljenosti u objašnjenju zastupljenosti anksioznih, depresivnih i somatizacijskih simptoma kod učitelja. Istraživanje je provedeno na uzorku od 1149 osnovnoškolskih učitelja predmetne nastave iz različitih hrvatskih regija. Ukupno je sudjelovalo 210 učitelja i 939 učiteljica u dobi između 24 i 65 godina. S obzirom su na rodne razlike u zastupljenosti pojedinih psihopatoloških simptoma provedene zasebne analize na poduzorcima učitelja i učiteljica. Provedbom je hijerarhijskih regresijskih analiza utvrđeno da, uz kontrolu duljine radnog staža (koja značajno doprinosi objašnjenju simptoma somatizacije kod učiteljica), određene emocije (zasićenost, ljubav, ljutnja i beznađe doživljene u odnosu s učenicima; anksioznost doživljena u odnosu s roditeljima, te doživljaj razočaranosti u obrazovni sustav), kao i doživljaj emocionalne iscrpljenosti ostvaruju značajne samostalne doprinose objašnjenju anksioznih, depresivnih i somatizacijskih simptoma učitelja. Dobiveni rezultati upućuju na to da objašnjenju psihopatoloških simptoma učitelja i učiteljica u najvećoj mjeri pridonosi doživljaj emocionalne iscrpljenosti kao posljedica svakodnevnog pritiska na poslu.

Ključne riječi: učitelji, emocije, emocionalna iscrpljenost, mentalno zdravlje, psihopatološki simptomi

Ivana Macuka, Odjel za psihologiju Sveučilišta u Zadru, Obala kralja Petra Krešimira IV br. 2, 23000 Zadar, Hrvatska. E-pošta: ivana.moranduzzo@unizd.hr

Istraživanje je provedeno u sklopu uspostavnoga istraživačkog projekta Hrvatske zaklade za znanost "Teachers' emotions and emotion regulation strategies: personal and contextual antecedents and effects on motivation, well-being and relationship with students (5035)". 


\section{Uvod}

Učiteljska profesija, osim što može biti izvor zadovoljstva, može biti i izrazito emocionalno iscrpljujuća (Philipp i Schüpbach, 2010). Učestali stresni uvjeti u učiteljskoj profesiji mogu dovesti do brojnih negativnih posljedica kao što je profesionalno sagorijevanje te, posljedično, i narušavanje mentalnog zdravlja učitelja. Neki autori navode kako je učiteljska profesija općenito jedna od emocionalno najzahtjevnijih profesija (Brotheridge i Grandey, 2002; Chang, 2009) te da u svom poslu učitelji mogu doživjeti širok raspon ugodnih, ali i neugodnih emocija značajnog intenziteta (Demetriou, Wilson i Winterbottom, 2009; Hagenauer i Volet, 2014; Sutton i Wheatley, 2003). Učiteljske emocije, kao sastavni dijelovi njihove profesije, imaju važnu ulogu u formiranju osjećaja profesionalnog identiteta, ali mogu utjecati i na mentalno zdravlje učitelja te je neupitan njihov utjecaj na kvalitetu obrazovanja u cjelini (Schutz, Cross, Hong i Osbon, 2007; Sutton, 2007; Sutton i Wheatley, 2003). Tek se u novije vrijeme uvažava činjenica da je za učitelje razredni (školski) kontekst izrazito "emocionalno mjesto", te da učitelji doživljavaju širok raspon pozitivnih (ljubav prema učenicima, radost, zadovoljstvo, ponos itd.) i negativnih emocija (ljutnja, frustracija, anksioznost, beznađe itd.) za vrijeme poučavanja (Burić, Slišković i Macuka, 2016).

Doživljene negativne emocije učitelja u radu poput anksioznosti, frustracije, tuge i beznađa (Demetriou, Wilson i Winterbottom, 2009; Hagenauer i Volet, 2014; Sutton i Wheatley, 2003) određuju njihovu psihološku dobrobit, zadovoljstvo poslom, emocionalnu iscrpljenost, sagorijevanje na poslu i zadržavanje $u$ nastavničkoj profesiji (Chang, 2009). S obzirom na različite uloge koje učitelji imaju u procesu poučavanja često su i izloženi situacijama koje od njih zahtijevaju povećanu odgovornost i emocionalni napor, čime se može stvoriti put ka emocionalnoj iscrpljenosti te, posljedično, izraženijim različitim psihopatološkim simptomima. Jedna je od češće istraživanih negativnih posljedica nastavničke profesije upravo emocionalna iscrpljenost, koja predstavlja ključni aspekt sindroma sagorijevanja (Masclach, Schaufeli i Leiter, 2001), a odnosi se na nepostojanje emocionalnih zaliha i fizičku iscrpljenost kao posljedicu svakodnevnog pritiska na poslu (Lee i Ashforth, 1996; Maslach i sur., 2001). Kada osjećaji emocionalne iscrpljenosti postanu kronični i prolongirani, posljedično mogu pridonijeti sagorijevanju na poslu i napuštanju nastavničke profesije (Chang, 2009). Bitno je naglasiti da emocionalna iscrpljenost nije karakteristična za sva zanimanja koja uključuju interakciju s drugima, već prvenstveno za ona zanimanja kod kojih su te interakcije dugotrajnije i emocionalno intenzivnije (Morris i Feldman, 1996). Posao socijalnog radnika, medicinske sestre i učitelja samo su neka od zanimanja kod kojih je pojava emocionalne iscrpljenosti gotovo neizbježna. Istraživanja o profesionalnom sagorijevanju učitelja u Hrvatskoj upućuju na to da osobito loše razredno ozračje emocionalno iscrpljuje učitelje te dovodi do razvijanja negativnih stavova prema učenicima i općenito poslu (Koludrović, Jukić i Reić Ercegovac, 2009). Nadalje, u nekim se hrvatskim istraživanjima navodi da se više od polovice 
učitelja osjeća emocionalno iscrpljeno poslom, a visok stupanj emocionalne iscrpljenosti povezan je s brojem učenika, vremenskim ograničenjem i radnim (pre)opterećenjem (Domović, Martinko i Jurčec, 2010; Martinko, 2010). Neka su se istraživanja usmjerila na proučavanje odnosa emocionalne iscrpljenosti s duljinom radnog staža učitelja. Rezultati su tih istraživanja nekonzistentni, tj. u nekim se navodi da mlađi učitelji (s manje radnog staža) doživljavaju veću emocionalnu iscrpljenost u odnosu na starije učitelje s duljim radnim stažem (Gold, 1985), dok druga istraživanja navode da učitelji s duljim radnim stažem pokazuju značajno veću emocionalnu iscrpljenost od početnika (Kokkinos, 2007; Zhongying, 2008). Ispitivanjem se rodnih razlika u doživljaju učiteljskog stresa u istraživanjima navodi da učiteljice navode više razine stresa $i$ to vjerojatno zbog viših razina u ukupnom doživljaju opterećenja (Antoniou, Polychroni i Vlachakis, 2006).

S obzirom se na istraživanja o ulozi različitih važnih čimbenika u obrazovnom procesu može reći da su učitelji u svom svakodnevnom radu pri ostvarivanju svojih profesionalnih ciljeva izloženi različitim zahtjevima posla koji mogu postati i izvori njihova stresa, te, posljedično, utjecati i na njihovu psihološku dobrobit. Odnosno, svakodnevne stresne situacije na poslu koje zahtijevaju učestali emocionalni napor i prilagođavanje dugoročno mogu nepovoljno djelovati i na mentalno zdravlje pojedinca, te učitelji koji doživljavaju povećane emocionalne zahtjeve u svom radnom okruženju mogu osjećati i tjeskobu, depresiju, tjelesne i druge poteškoće. Istraživanja koja su se bavila ispitivanjem profesionalnog stresa i psihološke dobrobiti između 26 skupina različitih zanimanja (Johnson i sur., 2005) navode da značajno veću izloženost negativnim posljedicama profesionalnog stresa imaju zdravstveni radnici, nastavnici, socijalni radnici, djelatnici u pozivnim centrima, policajci i zatvorski čuvari. Pri tome se navode različite posljedice profesionalnog stresa kao što su narušeno fizičko zdravlje, psihološka dobrobit i zadovoljstvo poslom. Karakteristično je za navedena rizičnija zanimanja naglašena emocionalna komponenta koja je relevantna za percepciju stresa na poslu (Zapf, 2002). Istraživanja o odnosu profesionalnog sagorijevanja i depresivnosti jasno navode značajne pozitivne odnose sagorijevanja na poslu i simptoma depresivnosti (Bakker, Schaufeli, Leiter i Taris, 2008; Hakanen, Schaufeli i Ahola, 2008) te različitih dimenzija doživljaja učiteljske profesije (osobito zahtjevnosti posla i niske socijalne podrške) sa simptomima anksioznosti i depresivnosti (Borrelli, Benevene, Fiorill, Amelio i Pozzi, 2014).

Slijedom navedenih spoznaja o zahtjevnosti učiteljske profesije i mogućim nepovoljnim ishodima na psihološku dobrobit učitelja u ovom se radu nastoji ispitati uloga različitih pozitivnih i negativnih emocionalnih iskustava učitelja te zasebno doživljaja emocionalne iscrpljenosti kao mogućih prediktora mentalnog zdravlja učitelja. Za ispitivanje mentalnog zdravlja učitelja, tj. zastupljenosti psihopatoloških simptoma, podaci o učestalosti simptoma anksioznosti, depresivnosti i somatizacije prikupljeni su na osnovu Derogatisova Kratkog inventara simptoma (Derogatis, 1993), koji omogućuje brzu procjenu izraženosti različitih simptoma kod odraslih osoba. Prednost je inventara što se može koristiti i sekvencijalno kako bi se zabilježili trendovi u zastupljenosti pojedinih simptoma tijekom vremena, te je stoga izabran u 
okviru longitudinalnoga istraživačkog projekta na učiteljima ${ }^{1}$. Iako su anksioznost $\mathrm{i}$ depresija usko povezani, te je čest i komorbiditet, oni se razmatraju kao zasebni problemi zbog razlika u karakterističnim simptomima (Barlow i Campbell, 2000). Kod anksioznosti je dominantna emocija strah, ali ona uključuje još i nervozu, napetost i izrazitu zabrinutost. Depresivni se simptomi temelje na emocijama tuge te su očite promjene $u$ raspoloženju, motivaciji, tjelesnom i motoričkom funkcioniranju kao i spoznaji (Ingram, 1990). Somatizacija se odnosi na pojavu tjelesnih simptoma koji se pojavljuju pod utjecajem negativnih emocionalnih stanja (glavobolja, osjećaj tjelesnoga umora i iscrpljenosti i sl.) (Derogatis, 1993).

Brigom se za mentalno zdravlje učitelja zasigurno djeluje na kvalitetu rada učitelja u obrazovnom procesu, a u ovom je istraživanju naglašena važnost emocionalne komponente učiteljske profesije u objašnjenju njihova mentalnog zdravlja. Stoga je cilj ovog istraživanja bio ispitati ulogu različitih pozitivnih i negativnih emocija koje učitelji mogu doživjeti u odnosu s učenicima u razredu, roditeljima i obrazovnim sustavom, kao i doživljaja emocionalne iscrpljenosti (kao aspekta sagorijevanja na poslu) $\mathrm{u}$ objašnjenju zastupljenosti različitih psihopatoloških simptoma učitelja. Konkretno, nastojalo se utvrditi može li se na temelju duljine radnog staža, doživljenih pozitivnih i negativnih učiteljskih emocija ( $u$ odnosu s učenicima, roditeljima i obrazovnim sustavom) te doživljaja emocionalne iscrpljenosti poslom predvidjeti zastupljenost anksioznih, depresivnih i somatizacijskih simptoma predmetnih učitelja. Ujedno su se ispitale i rodne razlike u zastupljenosti pojedinih psihopatoloških simptoma uz pretpostavku više izraženosti mjerenih simptoma kod učiteljica, u odnosu na učitelje. Pretpostavilo se da će radni staž učitelja značajno pridonijeti objašnjenju psihopatoloških simptoma učitelja, ali nekonzistentni rezultati istraživanja ne omogućuju postavljanje jednoznačnih hipoteza o ulozi radnog staža. Nadalje, pretpostavilo se da će se učestalo doživljavanje negativnih emocija u svakodnevnom radu u odnosu $\mathrm{s}$ učenicima, roditeljima i obrazovnim sustavom, uz percepciju izraženije emocionalne iscrpljenosti nepovoljno odraziti na psihološku dobrobit učitelja, tj. povećati zastupljenost psihopatoloških simptoma anksioznosti, depresivnosti i somatizacije.

\section{Metoda}

\section{Sudionici}

Istraživanje je provedeno na prigodnom uzorku učitelja predmetne nastave (od 5. do 8. razreda osnovne škole) iz različitih hrvatskih regija (Dalmacije, Istre, središnje Hrvatske i Slavonije). Ukupno je sudjelovalo 1149 učitelja (210 učitelja i

\footnotetext{
${ }^{1}$ Istraživanje je provedeno u sklopu uspostavnoga istraživačkog projekta Hrvatske zaklade za znanost "Teachers' emotions and emotion regulation strategies: personal and contextual antecedents and effects on motivation, well-being and relationship with students (5035)".
} 
939 učiteljice) u dobi između 24 i 65 godina $(M=40.79$; $S D=10.26)$. Prosječni je radni staž učitelja sudionika ovog istraživanja iznosio 14 godina $(M=14.05 ; S D=10.31)$.

\section{Mjerni instrumenti}

Upitnik učiteljskih emocija (Burić, Slišković i Macuka, 2016) omogućuje ispitivanje različitih pozitivnih (radost i ponos) i negativnih emocija (zasićenost, ljutnja, beznađe, anksioznost i razočaranost) koje učitelji mogu doživjeti u svom radu. Cjelokupni upitnik sadrži ukupno 88 tvrdnji kojima se obuhvaćaju emocije učitelja doživljene u odnosu s (1) učenicima (36 tvrdnji), (2) roditeljima (19 tvrdnji), (3) obrazovnim sustavom (14 tvrdnji) i (4) osobljem škole (19 tvrdnji). U ovom su istraživanju učitelji dali svoje procjene za emocije doživljene u odnosu s učenicima, roditeljima i obrazovnim sustavom na ukupno 69 tvrdnji na skali od 5 stupnjeva (1 $u$ potpunosti se ne slažem, do $5-u$ potpunosti se slažem). Za potrebe ovog istraživanja (i projekta u cjelini) konstruirana je nova supskala LJUBAV u odnosu s učenicima. Primjeri su tvrdnji za pojedine emocije: Sretna sam kad uspijem motivirati učenike. (RADOST u odnosu s učenicima); Osjećam se kao pobjednik kad moji učenici uspiju. (PONOS u odnosu s učenicima); Volim svoje učenike. (LJUBAV u odnosu s učenicima); Živcira me što pravilnike i zakone donose osobe koje nikad nisu radile u školi. (LJUTNJA u odnosu s obrazovnim sustavom); Bespomoćna sam jer do nekih roditelja ne dopire ništa što kažem. (BEZNAĐE u odnosu s roditeljima); Zbog nekih roditelja se brinem hoće li roditeljski sastanak dobro proći. (ANKSIOZNOST u odnosu s roditeljima). Ukupan se rezultat za pojedine emocije formira kao prosječan rezultat pripadajućih tvrdnji, a dobiveni viši rezultat upućuje na veću prisutnost mjerene emocije. Dobiveni koeficijenti pouzdanosti izraženi Cronbach alphom za pojedine emocije kreću se od .75 do .90 te potvrđuju dobra psihometrijska obilježja korištenog upitnika.

Skala iscrpljenosti je podljestvica Oldenburgova inventara sagorijevanja (Oldenburg Burnout Inventory - OLBI; Demerouti, Bakker, Vardakou i Kantas, 2003), koja je prevedena i adaptirana na hrvatski jezik u sklopu istraživačkog projekta. Supskala iscrpljenosti sadrži osam tvrdnji koje mjere različite osjećaje emocionalne iscrpljenosti izazvane radom. Ispitanici imaju zadatak procijeniti koliko se pojedina tvrdnja odnosi na njih zaokruživanjem odgovarajućeg broja na skali procjene od četiri stupnja (od 1 - uopće se ne slažem do 4-posve se slažem; primjer tvrdnje: Obično se osjećam umorno i istrošeno nakon posla.; Dok radim, često se osjećam emocionalno iscijeđeno.). Ukupni se rezultat ispitanika izračunava na osnovi prosjeka rezultata procjena na pojedinim tvrdnjama. Teoretski se raspon rezultata kreće između nula i četiri, pri čemu viši rezultat označava veće očitovanje učitelja o emocionalnoj iscrpljenosti poslom u školi. Skala u ovom istraživanju ima zadovoljavajuću pouzdanost uz koeficijent unutrašnje konzistencije od .84 .

Kratki inventar simptoma (BSI - Brief Symptom Inventory; Derogatis, 1993) upitnik je samoiskaza za procjenu psihopatologije i psihološke nelagode odraslih osoba i adolescenata. Ovaj upitnik mjeri trenutačni stupanj psihičkih simptoma 
nelagode izazvane stresnim životnim situacijama i koristi se i u kliničke i u istraživačke svrhe kada postoji potreba za relativno kratkom mjerom ispitanikove percipirane simptomatologije. Upitnik BSI se sastoji od 53 čestice koje mogu upućivati na psihološke simptome psihijatrijskih pacijenata i zdravih osoba iz opće populacije. Procjena se vrši na ljestvici od 5 stupnjeva $(0-4)$ u rasponu od 0 (nimalo) do 4 (vrlo mnogo). Ukupno mjeri devet dimenzija simptoma: somatizaciju, opsesivnu kompulzivnost, osjetljivost u međuljudskim odnosima, depresiju, anksioznost, neprijateljstvo, fobičnost, paranoidne ideje i psihoticizam. Za potrebe su ovog istraživanja korištene tri dimenzije: anksioznost, depresivnost i somatizacija. Dimenzija Anksioznost uključuje šest čestica koje opisuju simptome napetosti, nervoze, zatim napadaje panike te osjećaje užasa i prestrašenosti. Također uključuje i kognitivnu komponentu, osjećaj straha i neke tjelesne korelate anksioznosti (Nervoza ili unutarnja drhtavica; Osjećaj zastrašenosti). Dimenzija Depresija uključuje šest simptoma koji po opisu odgovaraju slici kliničke depresije (Osjećaj tuge; Osjećaj beznađa u odnosu na budućnost), a simptomi poremećaja raspoloženja se mogu vidjeti i u nedostatku motivacije i gubitku interesa u životu. Dimenzija Somatizacije sadrži sedam čestica koje su usmjerene na kardiovaskularni, probavni i respiratorni sustav te na ostale dijelove tijela koji mogu biti važni u funkcioniranju autonomnoga živčanog sustava. Ova dimenzija odražava nelagodu koja proizlazi iz percepcije tjelesne disfunkcije (malaksalost ili vrtoglavica, osjećaj mučnine ili uznemirenosti $u$ trbuhu). Individualni su rezultati učitelja formirani zbrajanjem prosječne vrijednosti svih odgovora zasebno na dimenziji anksioznosti, depresivnosti i somatizacije. Utvrđeni koeficijent unutarnje konzistencije izražen Cronbach alphom u ovom istraživanju iznosi .83 za anksioznost, .85 za depresivnost, te .87 za somatizaciju.

\section{Postupak}

Istraživanje je provedeno tijekom studenog 2015. godine u sklopu znanstvenoistraživačkog projekta Hrvatske zaklade za znanost "Teachers' emotions and emotion regulation strategies: Personal and contextual antecedents and effects on motivation, well-being and relationship with students". E-porukom, u kojoj je detaljno pojašnjena svrha istraživanja, kontaktirani su ravnatelji i stručni suradnici iz ukupno 152 škole iz hrvatskih regija (Dalmacije, Istre, središnje Hrvatske i Slavonije). Školama, odnosno stručnim suradnicima/ravnateljima koji su e-porukom pristali dobrovoljno sudjelovati u istraživanju (146 škola), poštom su dostavljeni upitnici za predmetne učitelje od 5. do 8. razreda. U slučaju da je samo stručni suradnik pristao pomoći u provedbi istraživanja, prije provedbe istraživanja tražila se i suglasnost ravnatelja škola e-poštom ili telefonskim kontaktom. Upitnici su školama poslani poštom te su distribuirani učiteljima posredstvom stručnih suradnika (psihologa) i/ili ravnatelja. Ukupno je 53\% kontaktiranih učitelja predmetne nastave iz različitih osnovnih škola diljem Hrvatske pristalo dobrovoljno sudjelovati u istraživanju. Kako bi se učiteljima osigurala anonimnost, zajedno s upitnicima 
dostavljene su im zasebne kuverte za povrat upitnika. U upitnicima je detaljno objašnjenja svrha istraživanja kao i upute o popunjavanju upitnika. Naglašeno je kako je sudjelovanje $u$ istraživanju dobrovoljno i anonimno. Nakon što su učitelji ispunili upitnike dostavili su ih suradniku/ravnatelju koji je ispunjene upitnike vratio na adresu voditelja projekta.

\section{Rezultati}

\section{Deskriptivni pokazatelji i korelacijske analize}

Budući da je normalna distribucija rezultata osnovan uvjet za primjenu parametrijskih analiza, pomoću Kolmogorov-Smirnovljeva (K-S) testa normaliteta distribucije provjereno je koliko raspodjele mjerenih varijabli odstupa od normalne distribucije. S obzirom na to da Kline (2005) navodi da su ekstremno odstupajuće distribucije one čiji je indeks spljoštenosti veći od 10, a indeks asimetričnosti veći od 3 , provjerene su i veličine tih indeksa te je utvrđeno da oni u ovom istraživanju ne prelaze navedene vrijednosti. Iz Tablice 1. vidljivo je da su rezultati pomaknuti prema višim vrijednostima kod pozitivnih emocija (radosti i ponosa) doživljenih u odnosu s učenicima, a rezultati koji se odnose na psihopatološke simptome pokazuju pozitivnu asimetriju, odnosno pomaknuti su prema nižim vrijednostima. Vrijednosti se Kolmogorov-Smirnovljeva testa kreću od 0.152 do 0.239 i svi su statistički značajni ( $p<.01)$. Ovi rezultati potvrđuju kako prisutnost mjerenih simptoma učitelja nije velika i ne distribuira se normalno. Dobiveni zasebni indeksi asimetričnosti i indeksi spljoštenosti nisu veliki i u okvirima su prihvatljivih za provedbu parametrijskih analiza (asimetričnost $<1$, spljoštenost $<3$, prema Klineu, 2005). Ujedno, parametrijski se postupci smiju koristiti ako su distribucije različitih skala podjednako asimetrične.

Preliminarnim su analizama ( $t$-testovima za nezavisne uzorke) ispitane rodne razlike u procjenama zastupljenosti anksioznih, depresivnih i somatizacijskih simptoma između učitelja $(n=210)$ i učiteljica $(n=939)$. Utvrđeno je da učiteljice doživljavaju više anksioznih simptoma $\left(t_{(1147)}=2.49, \quad p<.01\right)$, više depresivnih simptoma $\left(t_{(1147)}=2.66, p<.01\right)$ kao i simptoma somatizacije $\left(t_{(1147)}=3.16, p<.01\right) \mathrm{u}$ odnosu na učitelje. Za utvrđivanje se veličine rodnih razlika izračunao i Cohenov $d$ indeks, koji na supskali anksioznih simptoma iznosi $d=0.19$, na supskali depresivnih simptoma $d=0.21$, te na supskali somatizacije $d=0.23$. Vrijednosti dobivenih indeksa $d$ upućuju na to da se radi o relativno niskom efektu povećane zastupljenosti psihopatoloških simptoma kod učiteljica. Međutim, s obzirom na to da su rodne razlike u zastupljenosti pojedinih psihopatoloških simptoma ipak statistički značajne, pretpostavljene relacije među pojedinim mjerenim konstruktima u ovom istraživanju su analizirane zasebno na poduzorku učitelja i učiteljica. 


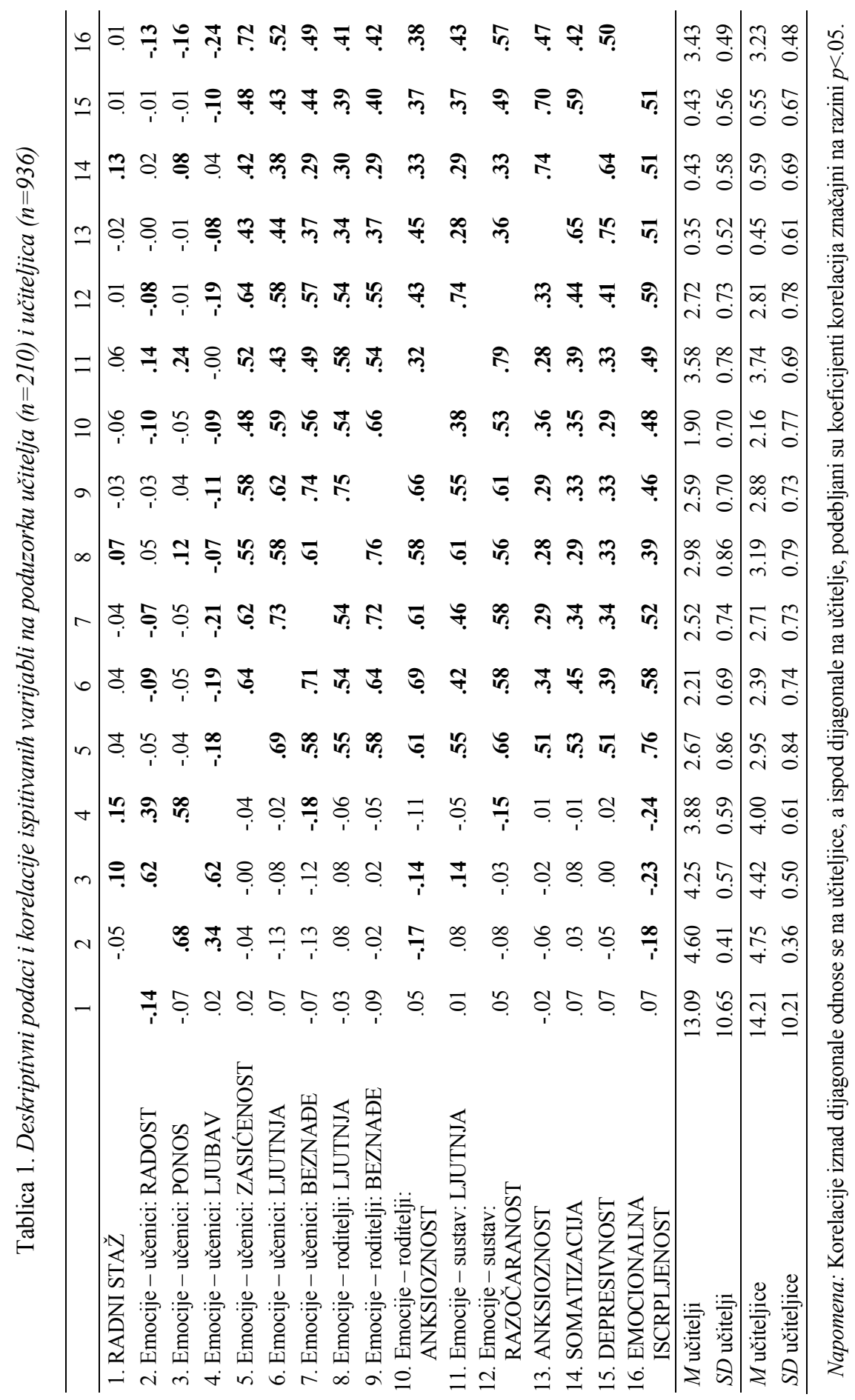


U Tablici 1. prikazani su osnovni deskriptivni pokazatelji i koeficijenti bivarijantnih korelacija među svim analiziranim varijablama $u$ ovom istraživanju utvrđenih na poduzorku učitelja ( $n=210$, ispod dijagonale) i poduzorku učiteljica ( $n=936$, iznad dijagonale). Prikazane su povezanosti duljine radnog staža, različitih emocija koje učitelji doživljavaju u odnosu s učenicima, roditeljima i obrazovnim sustavom, emocionalne iscrpljenosti učiteljskim poslom te različitih psihopatoloških simptoma učitelja (anksioznosti, depresivnosti i somatizacije).

Korelacije među varijablama upućuju na to da su i kod učitelja i kod učiteljica sva tri mjerena psihopatološka simptoma pozitivno povezana s procjenama doživljenih negativnih emocija u odnosu s učenicima, roditeljima i obrazovnim sustavom, kao i s doživljajem emocionalne iscrpljenosti poslom. Od doživljenih je pozitivnih emocija u odnosu s učenicima na poduzorku učiteljica izuzetak jedino značajna negativna korelacija između procjene percipirane ljubavi prema učenicima te anksioznosti i depresivnosti, te pozitivna korelacija između procjene doživljenog ponosa u odnosu s učenicima i somatizacijskih simptoma. Uvidom se u korelacijsku matricu može uočiti kako psihopatološke varijable najviše koreliraju s učiteljskim procjenama doživljene emocionalne iscrpljenosti poslom (učitelji i učiteljice koje izvještavaju o višem doživljaju emocionalne iscrpljenosti zbog svakodnevnog pritiska na poslu izvještavaju i o višoj zastupljenosti anksioznih, depresivnih i somatizacijskih simptoma). Što se tiče povezanosti kontrolne varijable duljine radnog staža sa zastupljenošću psihopatoloških simptoma učitelja, rezultati korelacijskih analiza upućuju na to da je duljina radnog staža povezana samo sa somatizacijskim simptomima učiteljica, pri čemu učiteljice s duljim radnim stažem u školskom kontekstu imaju zastupljenije somatizacijske simptome. Ukupno, korelacije su među varijablama u skladu s očekivanjima i opravdavaju analizu zasebnog doprinosa četiriju aspekata emocionalnih doživljaja učitelja u školskom kontekstu (doživljenih emocija u odnosu s učenicima, roditeljima, obrazovnim sustavom i doživljenom emocionalnom iscrpljenošću učitelja) objašnjenju zastupljenosti pojedinih psihopatoloških simptoma učitelja, uz kontrolu učinka duljine radnog staža učitelja.

\section{Doprinos emocija učitelja i emocionalne iscrpljenosti u objašnjenju anksioznosti, depresivnosti i somatizacije učitelja i učiteljica}

U daljnjim su analizama provedene hijerarhijske regresijske analize na poduzorcima učitelja i učiteljica u kojima su kriterijske varijable bile različiti psihopatološki simptomi (anksioznost, depresivnost i somatizacija), a prediktorske varijable uvođene su u regresijsku jednadžbu u ukupno pet koraka. Zasebne su hijerarhijske regresijske analize provedene na poduzorcima učitelja i učiteljica $s$ obzirom na to da su utvrđene rodne razlike u zastupljenosti pojedinih psihopatoloških simptoma, a ujedno je utvrđena statistički značajna povezanost između spola sa svim analiziranim emocijama (osim s emocijom razočaranosti $u$ odnosu na sustav) te 
emocionalnom iscrpljenošću, i to u korist učiteljica, što dodatno opravdava provedbu zasebnih analiza na poduzorcima.

U prvom je koraku uvedena kontrolna varijabla duljina radnog staža učitelja. U drugom su koraku u regresijsku analizu uvrštene doživljene emocije učitelja u odnosu s učenicima (radost, ponos, ljubav, zasićenost, ljutnja, beznađe). U trećoj su skupini uvedene emocije učitelja u odnosu s roditeljima (ljutnja, beznađe i anksioznost), u četvrtoj skupini emocije učitelja u odnosu s obrazovnim sustavom (ljutnja i razočaranost), a u petoj je skupini zasebno uvedena percipirana emocionalna iscrpljenost učitelja. Redoslijed je pojedinih skupina varijabli određen na osnovu pretpostavljene izloženosti doživljaja pojedinih emocija kod učitelja i emocionalne iscrpljenosti u objašnjenju različitih psihopatoloških simptoma. Ovakav način analiziranja omogućuje otkrivanje zasebnih doprinosa pojedinih skupina prediktora objašnjenju varijabiliteta različitih simptoma kod učitelja. Slijedi prikaz rezultata provedenih hijerarhijskih regresijskih analiza (Tablica 2., Tablica 3. i Tablica 4.) na poduzorcima učitelja i učiteljica za različite simptome (anksioznost, depresivnost i somatizaciju).

Tablica 2. Doprinos duljine radnog staža, emocija koje učitelji doživljavaju te emocionalne iscrpljenosti objašnjenju simptoma anksioznosti na poduzorku učitelja $(n=210)$ i učiteljica $(n=936)$

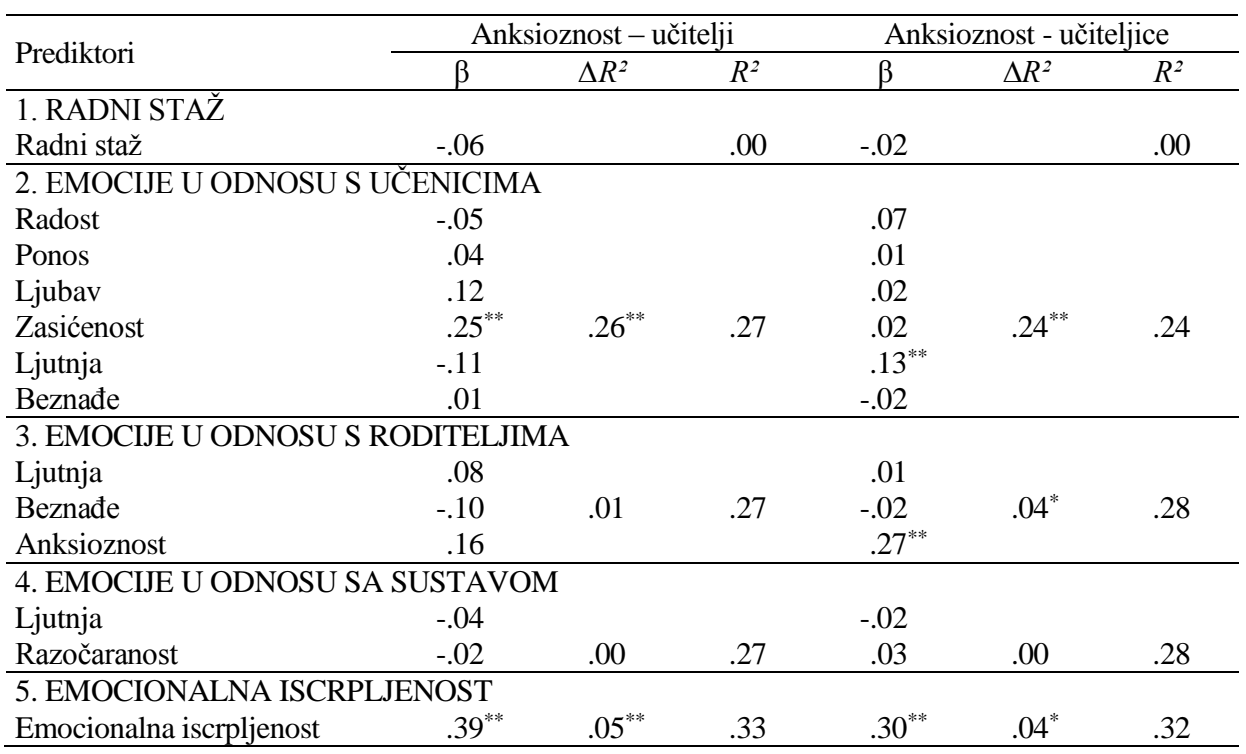

Napomena: Prikazani su rezultati zadnjeg koraka hijerarhijske regresijske analize: $\Delta R^{2}=$ doprinos pojedine grupe prediktora objašnjenoj varijanci; $R^{2}=$ ukupni doprinos prediktora objašnjenoj varijanci. ${ }^{*} p<.05 ;{ }^{* *} p<.01$. 
Rezultati hijerarhijske regresijske analize upućuju na to da kontrolna varijabla u prvom koraku analize (duljina radnog staža) ne objašnjava značajan dio varijance procjena simptoma anksioznosti učitelja. Nakon kontrole duljine radnog staža učiteljske procjene emocija doživljenih u odnosu s učenicima značajno su povećale postotak objašnjene varijance anksioznosti učitelja (za 26.4\%) i učiteljica (za 23.5\%). Na poduzroku je učitelja od doživljenih emocija u odnosu s učenicima značajan prediktor doživljena zasićenost $(\beta=.25, p<.01)$, a na poduzorku učiteljica doživljena ljutnja $(\beta=.13, p<.01)$ u odnosu s učenicima. Dobiveni rezultati upućuju na to da više simptoma anksioznosti doživljavaju oni učitelji koji u svom poslu doživljavaju više zasićenosti u odnosima s učenicima, te učiteljice koje doživljavaju više ljutnje u odnosima s učenicima. Emocije u odnosu s roditeljima, uvedene u trećem koraku, značajno ne povećavaju proporciju objašnjene varijance anksioznosti učitelja, kao ni emocije u odnosu s obrazovnim sustavom u četvrtom koraku analize. Na poduzorku učiteljica emocije u odnosu $\mathrm{s}$ roditeljima uvedene u trećem koraku značajno povećavaju proporciju objašnjene varijance anksioznosti učiteljica (za 4.2\%), a pri tome značajan doprinos ostvaruju procjene anksioznosti doživljene u odnosu $\mathrm{s}$ roditeljima $(\beta=.27, p<.01)$. Rezultati upućuju na to da više simptoma anksioznosti iskazuju učiteljice koje navode da doživljavaju i više anksioznosti u odnosu s

Tablica 3. Doprinos duljine radnog staža, emocija koje učitelji doživljavaju te emocionalne iscrpljenosti objašnjenju simptoma depresivnosti na poduzorku učitelja $(n=210)$ i učiteljica $(n=936)$

\begin{tabular}{|c|c|c|c|c|c|c|}
\hline \multirow{2}{*}{ Prediktori } & \multicolumn{3}{|c|}{ Depresivnost - učitelji } & \multicolumn{3}{|c|}{ Depresivnost - učiteljice } \\
\hline & $\beta$ & $\Delta R^{2}$ & $R^{2}$ & $\beta$ & $\Delta R^{2}$ & $R^{2}$ \\
\hline \multicolumn{7}{|l|}{ 1. RADNI STAŽ } \\
\hline Radni staž & .05 & & .01 & 02 & & .00 \\
\hline \multicolumn{7}{|c|}{ 2. EMOCIJE U ODNOSU S UČENICIMA } \\
\hline Radost & -.04 & & & .06 & & \\
\hline Ponos & .04 & & & -.01 & & \\
\hline Ljubav & .12 & & & .03 & & \\
\hline Zasićenost & .20 & $.27^{* * *}$ & .27 & .03 & $.27^{* *}$ & .27 \\
\hline Ljutnja & .01 & & & -.01 & & \\
\hline Beznađe & .05 & & & $.13^{* *}$ & & \\
\hline \multicolumn{7}{|c|}{ 3. EMOCIJE U ODNOSU S RODITELJIMA } \\
\hline Ljutnja & .14 & & & .05 & & \\
\hline Beznađe & -.03 & .01 & .28 & -.01 & $.01^{*}$ & .28 \\
\hline Anksioznost & -.12 & & & $.09^{*}$ & & \\
\hline \multicolumn{7}{|c|}{ 4. EMOCIJE U ODNOSU SA SUSTAVOM } \\
\hline Ljutnja & -.11 & & & -.05 & & \\
\hline Razočaranost & .15 & .01 & .29 & $.23^{* *}$ & $.03^{*}$ & .31 \\
\hline \multicolumn{7}{|c|}{ 5. EMOCIONALNA ISCRPLJENOST } \\
\hline Emocionalna iscrpljenost & $.34^{* *}$ & $.04^{*}$ & .33 & $.27^{* *}$ & $.03^{*}$ & .34 \\
\hline
\end{tabular}

Napomena: Prikazani su rezultati zadnjeg koraka hijerarhijske regresijske analize: $\Delta R^{2}=$ doprinos pojedine grupe prediktora objašnjenoj varijanci; $R^{2}=$ ukupni doprinos prediktora objašnjenoj varijanci. ${ }^{*} p<.05 ;{ }^{* *} p<.01$. 
roditeljima. U posljednjem koraku varijabla emocionalna iscrpljenost značajno povećava proporciju objašnjene varijance anksioznosti učitelja (za 5.2\%) i učiteljica (za 3.9\%), a rezultati upućuju na to da višu zastupljenost anksioznih simptoma navode učitelji ( $\beta=.39, p<.01)$ i učiteljice $(\beta=.30, p<.01)$, koje su više emocionalno iscrpljeni poslom. Mjerenim se skupom prediktorskih varijabli: duljinom radnog staža, emocija koje učitelji doživljavaju u odnosu s učenicima, roditeljima i sustavom te emocionalnom iscrpljenošću može ukupno objasniti $32.6 \%$ varijance anksioznosti učitelja i $32 \%$ varijance anksioznosti učiteljica.

Rezultati hijerarhijske regresijske analize za kriterijsku varijablu depresivnost također upućuju na to da kontrolna varijabla (duljina radnog staža) ne doprinosi značajno objašnjenju varijance depresivnih simptoma učitelja. Nakon kontrole duljine radnog staža učiteljske su procjene emocija doživljenih u odnosu s učenicima značajno povećale postotak objašnjene varijance procjena simptoma depresivnosti učitelja (za 26.6\%) i učiteljica (za 26.9\%). Od mjerenih emocija koje učitelji doživljavaju u odnosu s učenicima na temelju je završnog koraka hijerarhijske regresijske analize jedino na poduzorku učiteljica procjena beznađa u odnosu $\mathrm{s}$ učenicima $(\beta=.13, p<.05)$ ostvarila samostalni značajni doprinos u objašnjenju depresivnosti učiteljica. Više depresivnih simptoma iskazuju učiteljice koje u svom poslu u odnosu s učenicima doživljavaju više osjećaja beznađa. Emocije u odnosu s roditeljima, uvedene u trećem koraku, značajno povećavaju proporciju objašnjene varijance depresivnosti učiteljica (za $0.9 \%$ ), ali ne i učitelja, te značajan samostalni doprinos ostvaruju procjene doživljene anksioznosti u odnosu s roditeljima ( $\beta=.09$, $p<.05)$. Učiteljice koje iskazuju više simptoma depresivnosti iskazuju i više procjene anksioznosti doživljene u odnosu s roditeljima. U četvrtom koraku analize emocije u odnosu s obrazovnim sustavom ne doprinose značajno objašnjenju kriterijske varijable na poduzorku učitelja, ali na poduzorku učiteljica značajan doprinos ostvaruje procjena razočaranosti u odnosu s obrazovnim sustavom $(\beta=.23, p<.05)$. Na poduzroku učiteljica četvrti korak (emocije u odnosu s obrazovnim sustavom) značajno povećava postotak objašnjene varijance depresivnosti učiteljica (za 3.1\%) te dobiveni rezultat upućuje na to da višu zastupljenost depresivnih simptoma navode učiteljice koje su više razočarane obrazovnim sustavom. Nadalje, uvođenjem se emocionalne iscrpljenosti u posljednjem koraku analize značajno povećava proporcija objašnjene varijance depresivnosti učitelja (za 4\%) i učiteljica (za 3.2\%). Dobiveni rezultati upućuju na to da višu zastupljenost depresivnih simptoma navode učitelji $(\beta=.34, p<.01)$ i učiteljice $(\beta=.27, p<.01)$, koje procjenjuju višom emocionalnu iscrpljenost poslom u školi. Mjerenim se skupom prediktorskih varijabli za kriterijsku varijablu depresivnost može objasniti ukupno $32.8 \%$ varijance depresivnosti učitelja i $34.1 \%$ varijance depresivnosti učiteljica. 
Tablica 4. Doprinos duljine radnog staža, emocija koje učitelji doživljavaju te emocionalne iscrpljenosti objašnjenju simptoma somatizacije na poduzorku učitelja $(n=210)$ i učiteljica $(n=936)$

\begin{tabular}{|c|c|c|c|c|c|c|}
\hline \multirow{2}{*}{ Prediktori } & \multicolumn{3}{|c|}{ Somatizacija-učitelji } & \multicolumn{3}{|c|}{ Somatizacija- učiteljice } \\
\hline & $\beta$ & $\Delta R^{2}$ & $R^{2}$ & $\beta$ & $\Delta R^{2}$ & $R^{2}$ \\
\hline \multicolumn{7}{|l|}{ 1. RADNI STAŽ } \\
\hline Radni staž & .04 & & .01 & $.11^{* *}$ & & .02 \\
\hline \multicolumn{7}{|c|}{ 2. EMOCIJE U ODNOSU S UČENICIMA } \\
\hline Radost & .01 & & & .03 & & \\
\hline Ponos & .19 & & & .05 & & \\
\hline Ljubav & -.05 & & & $.01^{*}$ & & \\
\hline Zasićenost & .16 & $.30^{* *}$ & .31 & $.12^{* *}$ & $.21^{* *}$ & .22 \\
\hline Ljutnja & .17 & & & $.15^{* *}$ & & \\
\hline Beznađe & -.05 & & & -.08 & & \\
\hline \multicolumn{7}{|c|}{ 3. EMOCIJE U ODNOSU S RODITELJIMA } \\
\hline Ljutnja & -.06 & & & -.01 & & \\
\hline Beznađe & -.04 & .00 & .31 & -.02 & $.02 *$ & .24 \\
\hline Anksioznost & .03 & & & $.16^{* *}$ & & \\
\hline \multicolumn{7}{|c|}{ 4. EMOCIJE U ODNOSU SA SUSTAVOM } \\
\hline Ljutnja & .04 & & & .02 & & \\
\hline Razočaranost & .10 & .02 & .32 & .02 & .00 & .24 \\
\hline \multicolumn{7}{|c|}{ 5. EMOCIONALNA ISCRPLJENOST } \\
\hline Emocionalna iscrpljenost & $.29^{* * *}$ & $.03^{*}$ & .35 & $.27^{* *}$ & $.03^{*}$ & .27 \\
\hline
\end{tabular}

Napomena: Prikazani su rezultati zadnjeg koraka hijerarhijske regresijske analize: $\Delta R^{2}=$ doprinos pojedine grupe prediktora objašnjenoj varijanci; $R^{2}=$ ukupni doprinos prediktora objašnjenoj varijanci. ${ }^{*} p<.05 ;{ }^{* *} p<.01$.

Rezultati hijerarhijske regresijske analize za kriterijsku varijablu somatizacija upućuju na to da kontrolna varijabla u prvom koraku analize (duljina radnog staža) objašnjava značajan dio varijance procjena simptoma somatizacije učiteljica $(\beta=.11$, $p<.01$ ), ali ne i učitelja. Učiteljice $\mathrm{s}$ duljim radnim stažem iskazuju više somatizacijskih simptoma. Nakon kontrole duljine radnog staža učiteljske su procjene emocija doživljenih u odnosu s učenicima značajno povećale postotak objašnjene varijance somatizacije učitelja (za 30.3\%) i učiteljica (za 20.7\%). Na poduzorku učiteljica, na osnovu završnog koraka regresijske analize, doživljena ljubav $(\beta=.11, p<.05)$, zasićenost $(\beta=.12, p<.01)$ i ljutnja $(\beta=.15, p<.01)$ u odnosu $\mathrm{s}$ učenicima značajno pridonosi objašnjenju somatizacije učiteljica. Dobiveni rezultati upućuju na to da više simptoma somatizacije doživljavaju učiteljice, koje u svom poslu doživljavaju više ljubavi prema učenicima kao i zasićenosti i ljutnje u odnosima s učenicima. Emocije u odnosu s roditeljima, uvedene u trećem koraku, ne povećavaju značajno proporciju objašnjene varijance somatizacije učitelja, kao ni emocije u odnosu s obrazovnim sustavom u četvrtom koraku analize. Međutim, na poduzorku učiteljica emocije u odnosu s roditeljima uvedene u trećem koraku, kao i u prethodnim analizama, značajno povećavaju proporciju objašnjene varijance anksioznosti učiteljica (za 1.5\%), a pri tome značajan doprinos ostvaruju ponovno 
procjene anksioznosti doživljene u odnosu s roditeljima $(\beta=.16, p<.01)$. Rezultati upućuju na to da više somatizacijskih simptoma iskazuju učiteljice koje iskazuju i više procjene anksioznosti u odnosu s roditeljima. U posljednjem koraku, kao i kod drugih psihopatoloških simptoma, varijabla emocionalna iscrpljenost značajno povećava proporciju objašnjene varijance somatizacije učitelja (za 2.9\%) i učiteljica (za 3\%), a rezultati upućuju na to da višu zastupljenost somatizacijskih simptoma navode učitelji $(\beta=.29, p<.01)$ i učiteljice $(\beta=.27, p<.01)$, koje navode i višu emocionalnu iscrpljenost poslom u školi. Mjerenim se skupom prediktorskih varijabli za kriterijsku varijablu somatizacija može objasniti ukupno $35.3 \%$ varijance somatizacije učitelja i $27.2 \%$ varijance somatizacije učiteljica.

Zaključno, na osnovu provedenih hijerarhijskih regresijskih analiza rezultati upućuju na to da objašnjenju anksioznih, depresivnih i somatizacijskih simptoma učitelja i učiteljica u najvećoj mjeri pridonosi upravo doživljaj emocionalne iscrpljenosti kao posljedica svakodnevnog pritiska na poslu u školi.

\section{Rasprava}

Učestalo doživljavanje negativnih emocija uz osjećaj prolongirane emocionalne iscrpljenosti poslom zasigurno može pridonijeti narušavanju mentalnog zdravlja učitelja te je važno ispitivati ulogu emocionalne komponente učiteljske profesije u njihovoj psihološkoj dobrobiti. Cilj je ovog istraživanja bio utvrditi doprinose duljine radnog staža, različitih pozitivnih i negativnih emocija koje učitelji doživljavaju u odnosu s učenicima, roditeljima i obrazovnim sustavom te doživljaja emocionalne iscrpljenosti kao posljedice rada u školi u objašnjenju različitih psihopatoloških simptoma (anksioznosti, depresivnosti i somatizacije) predmetnih učitelja zaposlenih u osnovnim školama. Rezultati provedenog istraživanja velikim dijelom potvrđuju pretpostavke da učitelji koji doživljavaju učestalije negativne emocije u školskom kontekstu te procjenjuju i više razine emocionalne iscrpljenosti iskazuju i višu zastupljenost različitih psihopatoloških simptoma (anksioznosti, depresivnosti i somatizacije). U skladu $\mathrm{s}$ polazišnim očekivanjima o rodnim razlikama $\mathrm{u}$ zastupljenosti pojedinih psihopatoloških simptoma koje su potvrđene i u drugim istraživanjima (Derogatis, 1993; Macuka i Nekić, 2012), učiteljice u ovom istraživanju navode više razine mjerenih simptoma anksioznosti, depresivnosti i somatizacije $\mathrm{u}$ odnosu na učitelje, te su stoga analize u radu nezavisno provedene na poduzorcima učitelja i učiteljica. Provedbom je hijerarhijskih regresijskih analiza utvrđeno da uz kontrolu duljine radnog staža (koja značajno pridonosi objašnjenju simptoma somatizacije kod učiteljica), određene negativne i pozitivne emocije kao i doživljaj emocionalne iscrpljenosti (kod učitelja i učiteljica) ostvaruju značajne samostalne doprinose objašnjenju psihopatoloških simptoma na poduzorcima učitelja i učiteljica. Dobiveni rezultati upućuju na to da objašnjenju psihopatoloških simptoma učitelja i učiteljica u najvećoj mjeri pridonosi upravo doživljaj emocionalne iscrpljenosti, koji se odnosi na nepostojanje emocionalnih zaliha i 
fizičku iscrpljenost kao posljedicu svakodnevnog pritiska na poslu. Učitelji i učiteljice koji navode veću emocionalnu iscrpljenost poslom navode i više razine zastupljenosti različitih simptoma te su ove povezanosti identične u svim mjerenim simptomima (anksioznosti, depresivnosti i somatizacije) na poduzorcima učitelja i učiteljica i u skladu s drugim istraživanjima (Bakker i sur., 2008; Hakanen i sur., 2008). Međutim, za razliku od jasnog doprinosa varijable emocionalne iscrpljenosti poslom u školi, doprinosi duljine radnog staža i različitih negativnih i pozitivnih emocija razlikuju se na poduzorcima učitelja i učiteljica te upućuju na specifičnosti u emocionalnom doživljavanju i ulozi emocija doživljenih u školskom kontekstu u objašnjenju mentalnog zdravlja učitelja i učiteljica. Iako se, na temelju prethodnih istraživanja (Gold, 1985; Kokkinos, 2007; Zhongying, 2008) očekivao značajan doprinos duljine radnog staža učitelja u objašnjenju njihova mentalnog zdravlja, radni staž u ovom istraživanju značajno objašnjava jedino somatizacijske simptome učiteljica. Kada se poduzorci ispitanika razmataju odvojeno, objašnjenju anksioznih simptoma učitelja značajno doprinosi zasićenost doživljena u odnosu s učenicima te emocionalna iscrpljenost, a učiteljica ljutnja doživljena u odnosu s učenicima, anksioznost doživljena u odnosu s roditeljima i doživljaj emocionalne iscrpljenosti. Nadalje, objašnjenju depresivnih simptoma učitelja doprinosi emocionalna iscrpljenost, a učiteljica osjećaj beznađa doživljen u odnosu s učenicima, doživljaj anksioznosti u odnosu s roditeljima, doživljaj razočaranosti u obrazovni sustav te emocionalna iscrpljenost. Somatizaciji učitelja značajno pridonosi istaknutiji doživljaj emocionalne iscrpljenosti, a somatizaciji učiteljica duljina radnog staža, emocije ljubavi, zasićenosti i ljutnje doživljene u odnosu s učenicima, anksioznost doživljena u odnosu s roditeljima te emocionalna iscrpljenost. Zaključno, na temelju provedenih hijerarhijskih regresijskih analiza pokazuje se da učestale negativne emocije doživljene u odnosu s učenicima značajno pridonose, uz kontrolu duljine radnog staža, objašnjenju zastupljenosti različitih simptoma učitelja i učiteljica te da su pritom pojedine negativne emocije ostvarile i samostalan doprinos u objašnjenju različitih psihopatoloških simptoma učiteljica. No, suprotno očekivanjima o ulozi pozitivnih emocija, više su procjene ljubavi doživljene u odnosu s učenicima na poduzorku učiteljica značajno pozitivno pridonijele objašnjenju njihovih somatizacijskih simptoma. Moguće je da se učiteljice, koje su više emocionalno involvirane u odnose s učenicima te iskazuju i više ljubavi prema njima, ujedno i više emocionalno angažiraju $i$ troše $u$ razredu. Posljedično se viša emocionalna uključenost može odraziti i na višu zastupljenost somatizacijskih simptoma koji se odnose na nelagodu koja pak proizlazi iz percepcije tjelesne disfunkcije poput učestalije malaksalosti, vrtoglavice ili osjećaja uznemirenosti u trbuhu nakon emocionalnih izazovnih i učestalih situacija.

Nadalje, doprinos se emocija doživljenih u odnosu s roditeljima i obrazovnim sustavom razlikuje na poduzorcima učitelja i učiteljica, odnosno emocije doživljene u odnosu s roditeljima značajno objašnjavaju psihopatološke simptome učiteljica, ali ne i učitelja. Dobiveni rezultati upućuju na to da je doživljaj više razine emocije anksioznosti u odnosu s roditeljima prediktivan za višu zastupljenost anksioznih, 
depresivnih i somatizacijskih simptoma učiteljica. Preciznije, više psihopatoloških simptoma iskazuju učiteljice koje navode da doživljavaju i više anksioznosti u odnosu s roditeljima. Može se pretpostaviti da su učiteljice osjetljivije i više usmjerene na dobre odnose $\mathrm{s}$ roditeljima te imaju intenzivnije odnose s roditeljima $u$ odnosu na učitelje, ali su možda i više zabrinute reakcijama i zahtjevima roditelja te općenito više strahuju od njihovih upita/reakcija na informacijama ili roditeljskim sastancima. To potvrđuje i činjenica da je doprinos emocija u odnosu s roditeljima na poduzorku učiteljica značajan nakon kontrole emocija doživljenih u odnosu s učenicima na svim mjerenim psihopatološkim simptomima učiteljica. Značajni doprinosi emocija koje učiteljice doživljavaju u odnosu s roditeljima, a koji nisu utvrđeni na poduzorku učitelja, mogu upućivati na intenzivniju usmjerenost učiteljica na odnose s roditeljima. Zasebno analizirane emocije doživljene u odnosu s obrazovnim sustavom značajno su pridonijele objašnjenju jedino depresivnih simptoma učiteljica te upućuju na to da viša zastupljenost procjene razočaranosti učiteljica u obrazovni sustav doprinosi višoj zastupljenosti depresivnih simptoma učiteljica. Usporedba dobivenih rezultata $\mathrm{s}$ drugim istraživanjima o doprinosu učiteljskih emocija objašnjenju psihopatoloških simptoma učitelja nije moguća jer su općenito istraživanja učiteljskih emocija usmjerena na ispitivanje njihovih uzroka u obrazovnom kontekstu. Tako primjerice istraživanja koja proučavaju izvore učiteljskih emocija često među negativnim učiteljskim emocijama ističu anksioznost učitelja koju izazivaju učestale reforme obrazovnog sustava, nedisciplina u razredu, osjećaj nedovoljne pripremljenosti učitelja za podučavanje te loši odnosi s kolegama, roditeljima i obrazovnim sustavom (Bullough, Bullough i Mayes, 2006; Calderhead, 2001; Hargreaves, 2001). Nadalje, i druga istraživanja koja ispituju izvore učiteljskih emocija navode da se ljutnja kod učitelja u odnosima s učenicima manifestira zbog različitih razloga: nepoštivanja pravila u razredu i nedoličnog ponašanja učenika (Hargreaves, 2000), loših odnosa s kolegama (Erb, 2002) te neodgovornih roditelja, koji ne poštuju institucijske norme (Lasky, 2000). Nepoštivanje pravila u razredu, nedolično ponašanje učenika, neodgovorni roditelji te lijenost i loša postignuća učenika, koji se navode kao izvori negativnih emocija učitelja (Hargreaves, 2000; Lasky, 2000; Reyna i Weiner, 2001; Sutton i Wheatley, 2003), u kombinaciji sa svakodnevnim pritiscima i zahtjevima s kojima se učitelji susreću može dovesti do iscrpljenja emocionalnih zaliha te posljedično pridonijeti i razvoju psihopatoloških simptoma kod učitelja. Kada je riječ o istraživanjima mentalnog zdravlja učitelja, većina se istraživanja usmjerila na ispitivanje uloge doživljaja profesionalnog sagorijevanja, a ne učiteljskih emocija, u objašnjenju psihopatoloških simptoma učitelja (Bakker i sur., 2008; Hakanen i sur., 2008). I ovo istraživanje potvrđuje kako je emocionalna iscrpljenost (kao važna komponenta profesionalnog sagorijevanja) ostvarila značajan doprinos u objašnjenju psihopatoloških simptoma učitelja i učiteljica.

Općenito, dobiveni rezultati ovog istraživanja potvrđuju pretpostavke o važnosti doživljenih negativnih emocija i emocionalne iscrpljenosti u objašnjenju psihopatoloških simptoma učitelja. Na temelju se dobivenih rezultata mogu uočiti 
određeni rizični čimbenici koji pridonose izraženijim psihopatološkim simptomima učitelja, ali pritom treba naglasiti različiti doprinos ispitivanih učiteljskih emocija na poduzorcima učitelja i učiteljica. $\mathrm{S}$ obzirom su na razlike u veličini poduzoraka učitelja i učiteljica vrijednosti nekih regresijskih koeficijenata na poduzorku učitelja veće od dobivenih vrijednosti kod učiteljica, ali ipak nisu statistički značajne, što upućuje na razlike u statističkoj snazi na poduzorcima različite veličine. Nadalje, ovo istraživanje ima i određene nedostatke. Kao prvo, istraživanje je korelacijske prirode te ne može dati uvid u uzročno-posljedične odnose među analiziranim varijablama, a analizirane su varijable operacionalizirane kroz samoprocjene, koje uz sebe vežu nedostatke kao što su individualne razlike u sposobnostima introspekcije te socijalno poželjno odgovaranje. Također, raspon je variranja rezultata na simptomima anksioznosti, depresivnosti i somatizacije pomaknut prema nižim vrijednostima (jer se radi o zdravoj radnoj populaciji učitelja) što je moglo dovesti do nižih korelacija s ostalim analiziranim varijablama. Potrebno je naglasiti kako su u istraživanju sudjelovali samo učitelji koji su bili voljni upoznati se s istraživanjem i ispuniti upitnike, a sudjelovalo je nešto više od 50\% kontaktiranih učitelja, te se postavlja pitanja jesu li dobrovoljno pristali sudjelovati učitelji s izraženijim problemima ili dobro prilagođeni učitelji. Nadalje, iako im je naglašena anonimnost u prikupljanju podatka, ne može se isključiti činjenica da su učitelji svjesni važnosti svojeg zanimanja, kao i očekivanja drugih te da postoji vjerojatnost da su prikupljeni odgovori odraz i socijalno poželjnih odgovora. Također, pri interpretaciji se uloge emocionalnih iskustava u mentalnom zdravlju učitelja u budućim istraživanjima treba usmjeriti i na ulogu nekih individualnih osobina učitelja. Odnosno, pored okolinskih rizičnih čimbenika unutar školskog konteksta u daljnjim je istraživanjima potrebno uzeti u obzir i doprinos nekih individualnih osobina učitelja, primjerice nekih osobina ličnosti (neuroticizma, savjesnosti), osjećaja profesionalne kompetentnosti učitelja i samoefikasnosti, sklonosti za kontrolom situacije i perfekcionizma. Krajnji je cilj ovog istraživanja upoznati znanstvenu i stručnu javnost s emocionalnim izazovima učiteljske profesije, ali i njihovim problemima. S obzirom na to da učiteljska profesija spada u emocionalnu zahtjevnu profesiju zbog koje su učitelji podložniji profesionalnom sagorijevanju, ovakva istraživanja pridonose boljem razumijevanju zahtjeva učiteljske profesije i potencijalnom razvoju mjera zaštite mentalnog zdravlja učitelja. Drugim riječima, na temelju se ovakvih istraživanja mogu ponuditi praktične smjernice za kreiranje obrazovnih programa budućih učitelja jer da bi se pogodovalo emocionalnom životu sudionika obrazovnih procesa, nužno je upozoriti i na važnost prepoznavanja negativnih emocija koje se pojavljuju u radu, a čija dugotrajna učestalost može, posljedično, dovesti do emocionalne iscrpljenosti, tj. sagorijevanja, narušenoga mentalnog zdravlja, smanjenog zadovoljstva u radu i napuštanja profesije. 


\section{Literatura}

Antoniou, A.S., Polychroni, F. i Vlachakis, A.N. (2006). Gender and age differences in occupational stress and professional burnout between primary and high-school teachers in Greece. Journal of Managerial Psychology, 21, 682-690.

Bakker, A.B., Schaufeli, W.B., Leiter, M.P. i Taris, T.W. (2008). Work engagement: An emerging concept in occupational health psychology. Work \& Stress, 22, 187-200.

Barlow, D.H. i Campbell, L.A. (2000). Mixed-anxiety depression and its implications for models of mood and anxiety disorders. Comprehensive Psychiatry, 41(2), 55-60.

Borrelli, I., Benevene, P., Fiorill, C., Amelio, F.D. i Pozzi, G. (2014). Working conditions and mental health in teachers: A preliminary study. Occupational Medicine, 64, 530-532.

Brotheridge, C.M. i Grandey, A.A. (2002). Emotional labor and burnout: Comparing two perspectives of "people work". Journal of Vocational Behavior, 60(1), 17-39.

Bullough, R.V., Bullough, D.A.M. i Mayes, P.B. (2006). Getting in touch: Dreaming, the emotions and the work of teaching. Teachers and Teaching: Theory and Practice, 12(2), 193-208.

Burić, I., Slišković, A. i Macuka, I. (2016). Capturing teachers' emotions: Development and initial validation of Teacher Emotion Questionnaire. Unpublished manuscript.

Calderhead, J. (2001). International experiences of teaching reform. U: V. Richardson (Ur.), Handbook of research on teaching (str. 777-802). Washington: American Educational Research Association.

Chang, M.L. (2009). An appraisal perspective of teacher burnout: Examining the emotional work of teachers. Educational Psychology Review, 21, 193-218.

Demerouti, E., Bakker, A.B., Vardakou, I. i Kantas, A. (2003). The convergent validity of two burnout instruments: A multitrait-multimethod analysis. European Journal of Psychological Assessment, 19, 12-23.

Demetriou, H., Wilson, E. i Winterbottom, M. (2009). The role of emotion in teaching: Are there differences between male and female newly qualified teachers' approaches to teaching? Educational Studies, 35(4), 449-473.

Derogatis, L.R. (1993). Brief Symptom Inventory (BSI) - Administration, scoring and procedures manual. Minneapolis: NCS Pearson, Inc.

Domović, V., Martinko, J. i Jurčec, L. (2010). Čimbenici učiteljskog sagorijevanja na poslu. Napredak, 151(3-4), 350-369.

Erb, C.S. (2002). The emotional whirlpool of beginning teachers' work. Paper presented at the annual meeting of the Canadian Society of Studies in Education, Toronto, Canada.

Gold, Y. (1985). Does teacher burnout begin with student. Teaching Education, 105(3), 254257.

Hagenauer, G. i Volet, S.E. (2014). Teacher-student relationship at university: An important yet under-researched field. Oxford Review of Education, 40(3), 370-388. 
Hakanen, J.J., Schaufeli, W.B. i Ahola, K. (2008). The job-demands-resources model: A three-year cross-lagged study on burnout, depression, commitment, and work engagement. Work \& Stress, 22, 224-241.

Hargreaves, A. (2000). Teachers' perceptions of their interactions with students. Teaching and Teacher Education, 16(8), 811-826.

Hargreaves, A. (2001). Beyond anxiety and nostalgia: Building a social movement for educational change. The Phi Delta Kappan, 82(5), 373-377.

Johnson, S., Cooper, C., Cartwright, S., Donald, I., Taylor, P. i Millet, C. (2005). The experience of work-related stress across ocupations. Journal of Managerial Psychology, 20(2), 178-187.

Ingram, R.E. (1990). Contemporary psychological approaches to depression. Plenum Press. New York and London.

Kline, R.B. (2005). Principles and practice of structural equation modeling. New York: The Guilford Press.

Kokkinos, C.M. (2007). Job stressors, personality and burnout in primary school teachers. British Journal of Educational Psychology, 77, 229-243.

Koludrović, M., Jukić, T. i Reić Ercegovac, I. (2009). Sagorijevanje na poslu kod učitelja razredne i predmetne nastave te srednjoškolskih učitelja. Život $i$ škola, 22, 235-249.

Lasky, S. (2000). The cultural and emotional politics of parent - teacher interaction. Teaching and Teacher Education, 16(8), 843-860.

Lee, R. i Ashforth, B.E. (1996). A meta-analytic examination of the correlates of the three dimensions of job burnout. Journal of Applied Psychology, 81, 123-133.

Macuka, I. i Nekić, M. (2012). Uloga individualnih karakteristika roditelja u objašnjenju dječjih internaliziranih i eksternaliziranih problema. Socijalna psihijatrija, 40(2), 97109.

Martinko, J. (2010). Profesionalno sagorijevanje na poslu učitelja u obrazovanju odraslih. Andragoški glasnik, 14(2), 99-110.

Maslach, C., Schaufeli, W.B. i Leiter, M.P. (2001). Job burnout. Annual Review of Psychology, 52, 397-422.

Morris, J.A. i Feldman. D.C. (1996). The dimensions, antecedentes, and consequences of emotional labor. Academy of Management Review, 21(4), 986-1010.

Philipp, A. i Schüpbach, H. (2010). Longitudinal effects of emotional labour on emotional exhaustion and dedication of teachers. Journal of Occupational Health Psychology, 15(4), 494-504.

Reyna, C. i Weiner, B. (2001). Justice and utility in the classroom: An attributional analysis of the goals of teachers' punishment and intervention strategies. Journal of Educational Psychology, 93(2), 309-319. 
Schutz, P.A., Cross, D.I., Hong, J.LY. i Osbon, J.N. (2007). Teachers identities, beliefs, and goals related to emotions in the classroom. U: P.A. Schutz i R. Pekrun (Ur.), Emotion in education (str. 223-227). London: Educational Psychology Series.

Sutton, R. (2007). Teachers' anger, frustration, and self-regulation. U: P.A. Schutz i R. Pekrun (Ur.), Emotion in education (str. 259-274). San Diego, CA: Academic Press.

Sutton, R.E. i Wheatley, K.F. (2003). Teacher's emotion and teaching: A review of the literature and directions for future research. Educational Psychology Review, 15(4), 327358.

Zapf, D. (2002). Emotion work and psychological well-being: A review of the literature and some conceptual considerations. Human Resource Management Review, 1-32.

Zhongying, S. (2008). Current situation of job burnout of junior high school teachers in Shangqiu urban areas and its relationship with social support. Frontiers of Education in China, 3(2), 295-309.

\title{
Emotional Experiences as Predictors of Teachers' Mental Health
}

\begin{abstract}
Teaching profession is considered emotionally demanding since teachers experience a variety of positive and negative emotions of significant intensity at work. Emotions they experience in relation to their professional activities can affect their professional and personal development. Frequent experiences of teachers' negative emotions in relation to students, parents, colleagues or educational system in general as well as feelings of emotional exhaustion (as an important aspect of burnout), can have a negative impact on teachers' psychological well-being and increase the occurrence of psychopathological symptoms. The aim of this study was to examine the role of emotions (experienced in relation to students, parents, and educational system) and emotional exhaustion in explaining symptoms of anxiety, depression, and somatization among teachers. The study was conducted on a sample of 1149 subject-specific elementary school teachers from different regions in Croatia. A total of 210 male and 939 female teachers, aged between 24 and 65, participated in the study. Considering the expected gender differences in the prevalence of psychopathological symptoms, hierarchical regression analyses were conducted separately on the subsamples of male and female teachers. Results showed that, after controlling for working experience (which explains the somatization symptoms), certain emotions (exhaustion, love, anger, and hopelessness experienced in relation to students; anxiety experienced in relation to parents; and disappointment with educational system) and emotional exhaustion significantly explain the symptoms of anxiety, depression, and somatization among teachers. The obtained results emphasise the importance of emotional exhaustion, which results from daily stressors and pressures at work, in explaining psychopathological outcomes in the teaching profession.
\end{abstract}

Keywords: teachers, emotions, emotional exhaustion, mental health, psychopathological symptoms 


\section{Experiencias emocionales de maestros como predictores de su salud mental}

\section{Resumen}

El oficio de maestro pertenece al grupo de oficios emocionalmente exigentes y los maestros afirman que en su trabajo experimentan varias emociones agradables y desagradables de intensidad significativa. Diferentes emociones que los maestros experimentan en relación con sus actividades profesionales pueden influir en su desarrollo tanto profesional, como personal. Frecuentes emociones negativas en su trabajo cotidiano con los alumnos, padres, colegas y superiores, junto con la sensación de agotamiento emocional (como aspecto importante del agotamiento en el trabajo), pueden reflejarse negativamente al bienestar psicológico de los maestros y aumentan la presencia de los síntomas psicopatológicos.

En esta investigación se ha examinado el papel de diferentes emociones que los maestros pueden experimentar en su relación con los alumnos, padres y sistema educativo, igual que la sensación del agotamiento emocional para explicar los síntomas ansiosos depresivos y somatizados. La investigación se ha llevado a cabo en la muestra de 1149 maestros que enseñan cierta materia en colegio. Participaron 210 maestros y 939 maestras de toda Croacia que tienen la edad de entre 24 y 65 años. Tomando en consideración las diferencias de género para determinar la presencia de ciertos síntomas psicopatológicos, se han llevado a cabo análisis separados para las submuestras de maestros y maestras. Teniendo en cuenta también años de servicio (que contribuyen significativamente a la explicación de lo síntomas de somatización de las maestras), a través de los análisis de la regresión jerárquica se ha determinado que ciertas emociones (saciedad, amor, cólera y desesperación experimentadas en la relación con los alumnos, ansiedad experimentada en la relación con los padres y decepción en cuanto al sistema educativo), tanto como la sensación de agotamiento emocional, contribuyen significativamente (cada uno de ellos) a la explicación de síntomas ansiosos, depresivos y somatizados de los maestros. Los resultados obtenidos indican que lo que más contribuye a la explicación de síntomas psicopatológicos que muestran los maestros y las maestras es la sensación de agotamiento emocional como consecuencia de la presión cotidiana en el trabajo.

Palabras claves: maestros, emociones, agotamiento emocional, salud mental, síntomas psicopatológicos 